\title{
Macrofauna investigations along a transect from the inner German Bight towards the Dogger Bank*
}

\author{
I. Kröncke**, E. Rachor \\ Alfred-Wegener-Institute for Polar and Marine Research, Columbusstraße, W-2850 Bremerhaven, Germany
}

\begin{abstract}
During the Bremerhaven Workshop in March 1990 macrofauna samples were taken at 9 stations along a transect from the inner German Bight towards the offshore area of the Dogger Bank. Several statistical methods, univariate and multivariate, were applied to identify and describe changes in the communities along this profile. In general, 3 well-described communities were encountered: the Nucula-nitidosa-community in the inner German Bight, the Amphiura-filformis-community from the former Pleistocene valley of the River Elbe and the Tellina-fabula-community from the Dogger Bank. These sediment dependent structures combined with changes due to increasing distance from the shore (including increasing water depth) are superimposed on possible additional changes due to pollution or eutrophication and veil them along the gradient investigated. Thus, indications of impact can only be suggested within the communities. However, even the most of fshore Dogger Bank station appears to be disturbed.
\end{abstract}

\section{INTRODUCTION}

Hagmeier (1925) investigated the benthic macrofauna of the German Bight quantitatively for the first time in 1923, and this study was followed by several investigations (see Rachor 1990). During the workshop in March 1990 macrofauna samples were taken along a transect from the inner German Bight towards the Dogger Bank to describe changes in the benthic communities due to gradients in environmental conditions, to provide the other groups of the workshop with ecological background information and to allow for comparison of results.

\section{METHODS}

Area of investigation. In March 1990, 9 stations were sampled along the transect from the inner

- This is Publication no. 517 of the Alfred-Wegener-Institute for Polar and Marine Research, Bremerhaven

- Present address: Forschungsinstitut Senckenberg, Schleusenstr. 39a, W-2940 Wilhelmshaven, Germany
German Bight towards the Dogger Bank (Stebbing \& Dethlefsen 1992). The depth in the area of investigation varied between $19 \mathrm{~m}$ in the inner German Bight and $43 \mathrm{~m}$ in the Oyster Ground. The sediments were mud (inner German Bight), muddy sands in the intermediate area (Elbeurstromtal, the submerged Pleistocene Elbe valley, and Oyster Ground) and fine sands (Dogger Bank)

Sampling and sample treatment. At Stns 1 to 5, 6 replicates were taken with a $0.1 \mathrm{~m}^{2}$ van Veen grab; at Stations 6 to 9,3 replicates with a $0.2 \mathrm{~m}^{2}$ van Veen grab. The differences in the grab sizes were due to the fact that several vessels were involved in taking these samples. The intended pre-workshop sampling with one method in February 1990 failed because of very stormy weather.

All the samples were sieved over $1 \mathrm{~mm}$ screens and fixed in $4 \%$ buffered formalin. For biomass the wet weights of all species were determined separately.

Descriptive statistics. Due to the different grab sizes we ran all analyses with a total sample size of $0.6 \mathrm{~m}^{2}$. Diversity was calculated by the Shannon-Wiener index (Shannon \& Weaver 1972), evenness according to 

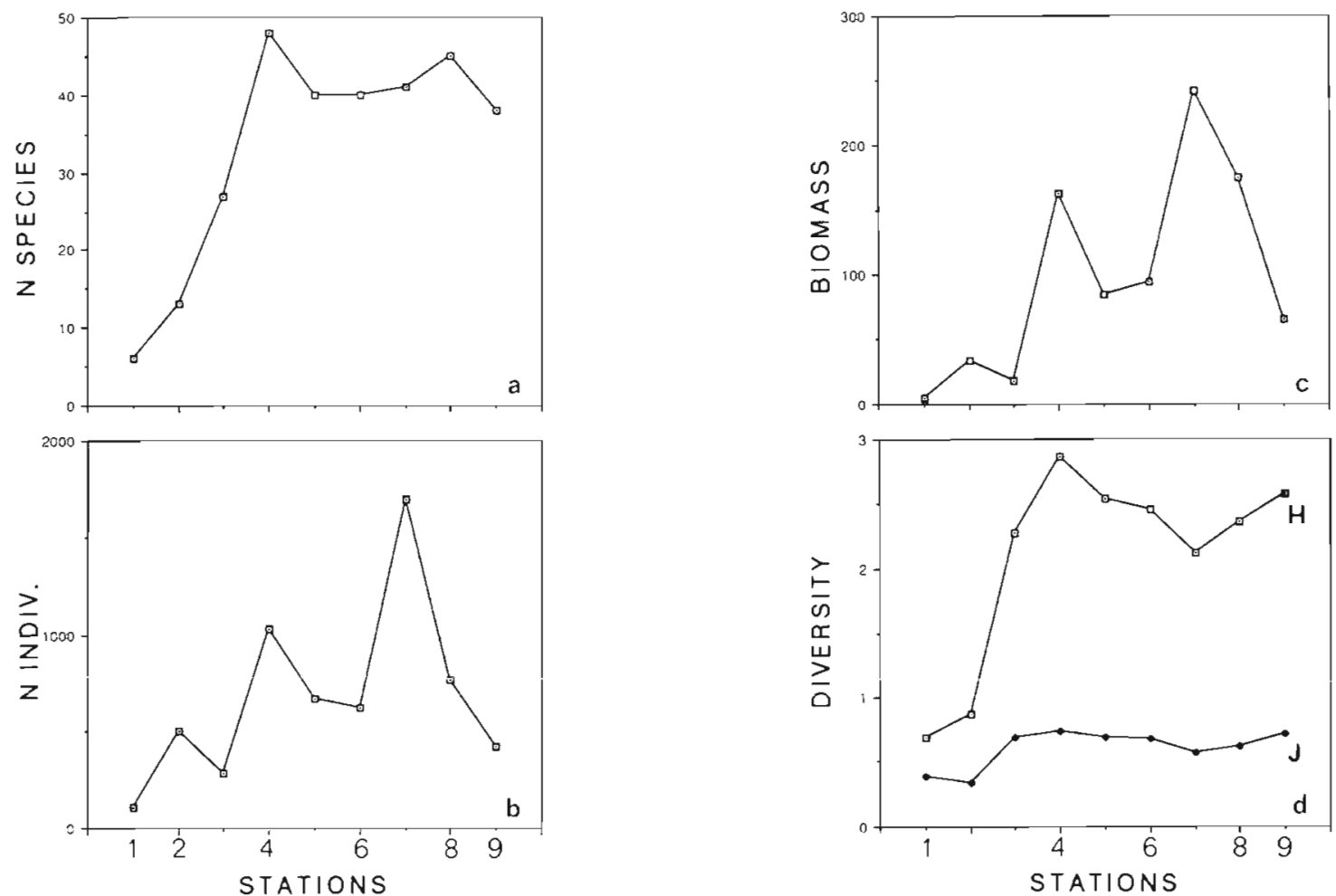

Fig. 1. (a) Species numbers, (b) individual numbers, (c) biomass ( $g$, wet weight), (d) diversities $H^{\prime}$ and evenness $J$ per $0.6 \mathrm{~m}^{2}$ for Stns 1 to 9 of the German Bight transect

Pielou (1969). To elucidate differences in diversity without doubt due to the different grabs used, rarefaction curves according to Sanders (1968) and Omori \& Ikeda (1984) were plotted. The expected species numbers were calculated as the $\log _{10}$ of the densities from assumed subsamples $[P(n)<10,<100,<200, \ldots<1000$ etc.]. Therefore, the plots are more or less approximated curves.

In addition, Abundance-Biomass Comparison (ABC) curves, based on Lambshead et al.'s (1983) k-domi-

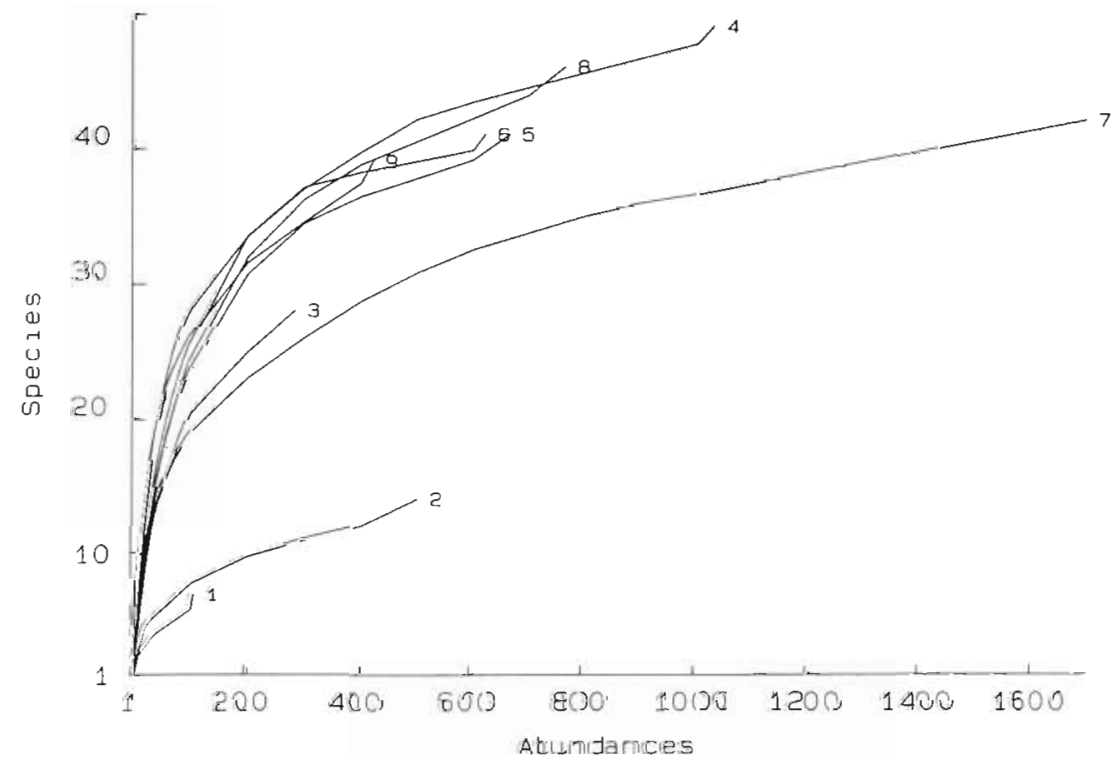

Fig. 2. Rarefaction abundance curves for Stns 1 to 9 
nance curves, were plotted. Warwick suggested that the relations between abundance and biomass curves may indicate pollution-induced stress (Warwick 1986, Warwick et al. 1987). For an undisturbed community the biomass is expected to lie above the abundance curve. In case of moderate disturbance the 2 curves are close together, and under high disturbance the biomass lies beneath the abundance curve.

Multivariate statistics. For classification, cluster analyses were performed using the indices of BrayCurtis (with percentages of individuals per species; Bray \& Curtis 1957) and of Jaccard (presence/absence of species; Jaccard 1912). Prior to computation, the data were transformed with $\log _{10}(n+1)$. For clustering, the 'unweighted pair group method' (UPGMA) was applied. Multidimensional Scaling (MDS) was carried out using the technique of Kruskal \& Wish (1978). For this analysis two of the $0.1 \mathrm{~m}^{2}$ samples from all Stns 1 to 5 were combined to obtain 3 replicates as at Stns 6 to 9 .

\section{RESULTS}

The species and individual numbers generally increased from the inner German Bight towards the open sea (Fig. 1a, b; values are summed up for the whole area sampled per station, $\left.0.6 \mathrm{~m}^{2}\right)$. On the Dogger Bank (Stn 9) slightly lower numbers were found. At Stn 1 only 6 species and 105 individuals were recorded; highest numbers occurred at Stns 4 \& 7 with 48 species and 1029 individuals and 41 species and 1692 individuals respectively. Biomass was low at Stns 1 to 3 , rose until Stn 7 and then declined at Stns 8 $\& 9$ (Fig. 1c)

Diversity and evenness increased significantly towards the open sea, with highest diversities at Stns 4 \& 9 (Fig. 1d). Although we used different grab sizes, by applying the rarefaction method, we can show by the very similar ranks of diversities that the ShannonWiener index was a genuine community parameter and not strongly dependent on the grab size (Fig. 2). a

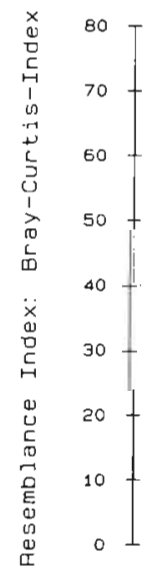

Station b

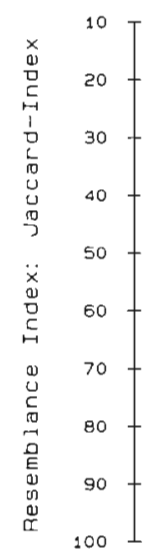

Station
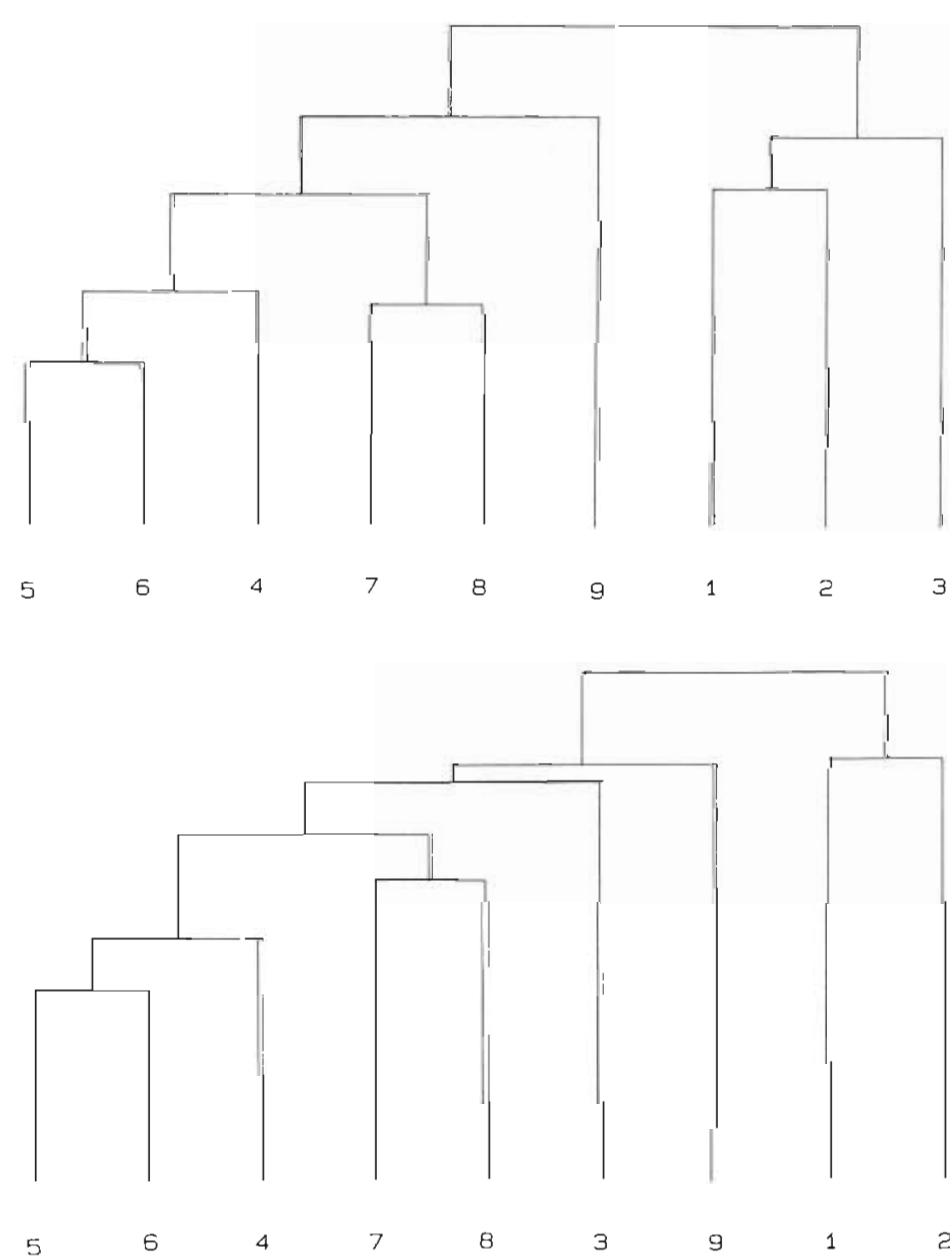

Fig. 3. Clusters according to the abundances of species at Stns 1 to 9 using (a) Bray-Curtis and (b) Jaccard index 


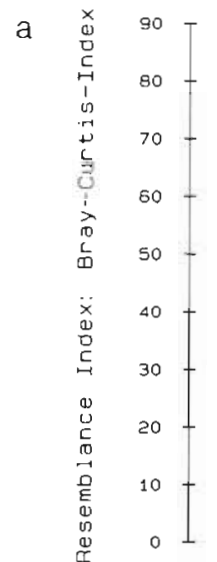

Station

b

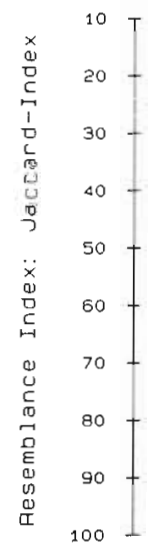

Station
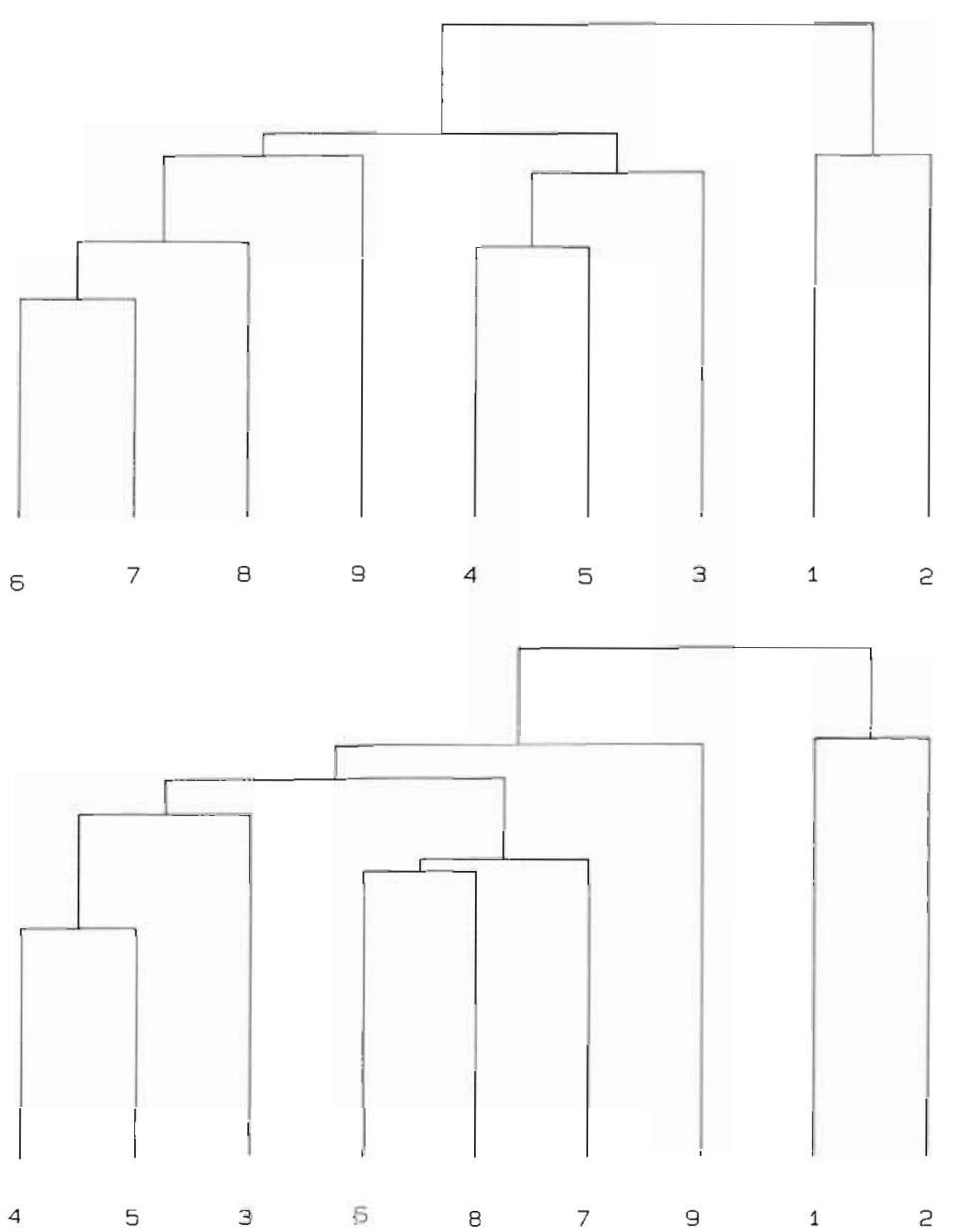

Fig. 4. Clusters according to the biomass of species at Stns 1 to 9 using (a) Bray-Curtis and (b) Jaccard index
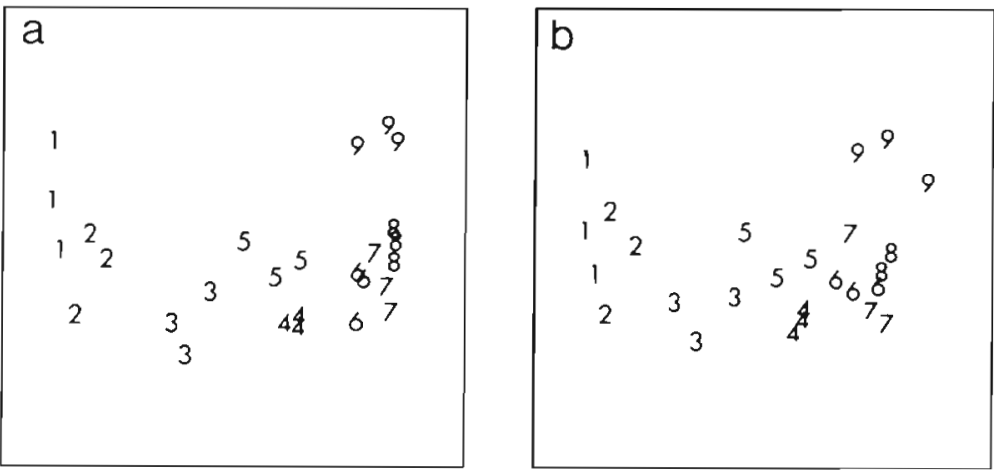

Fig. 5. Multidimensional scaling plots for (a) macrofauna abundance and (b) biomass along the German Bight transect. Station numbers are shown

This is especially true for the lowest ranks (Stns 1,2 \& 7). Stns 3 to 5 , sampled with the smaller grab, had diversities similar to that of Stns 6 to 9 , where the larger grab was used.

The cluster analyses generated similar results for abundances and biomass using the Bray-Curtis and the Jaccard index: one cluster for the inner German Bight (Stns 1 to 3), a second one for Stns 4 to 6 and a third one for Stns 7 to 9 (Figs. $3 \& 4$ ). However, some marginal stations were shifted to one or the other neighbouring cluster by the different methods used. By superimposing all results, the subsequent 'core 
Table 1. Dominating species of the main macrofauna communities in the German Bight during this study, March 1990

\begin{tabular}{|c|c|}
\hline Species & Abundance (ind. $\mathrm{m}^{-2}$ ) \\
\hline \multicolumn{2}{|l|}{ a. Cluster of Stns 1-3: } \\
\hline Nucula nitida & 307 \\
\hline Nephtys hombergii & 67 \\
\hline Nephtys ciliata & 27 \\
\hline Scoloplos armiger & 23 \\
\hline Ophiura albida & 12 \\
\hline Nephtys cirrosa & 9 \\
\hline Diastylis rathkei & 7 \\
\hline Abra nitida & 6 \\
\hline Notomastus latericeus & 5 \\
\hline Owenia fusiformis & 5 \\
\hline Pectinaria koreni & 3 \\
\hline Leiocarcinus holsatus & 2 \\
\hline \multicolumn{2}{|l|}{ b. Cluster of Stns 4-8: } \\
\hline Amphiura filiformis & 392 \\
\hline Mysella bidentata & 231 \\
\hline Scoloplos armiger & 90 \\
\hline Ophiura albida & 85 \\
\hline Nucula nitida & 74 \\
\hline Thyasira flexuosa & 68 \\
\hline Nephtys hombergii & 67 \\
\hline Magelona spp. & 65 \\
\hline Phoronis spp. & 63 \\
\hline Lanice conchilega & 62 \\
\hline Pholoe minuta & 37 \\
\hline Harpinia antennaria & 30 \\
\hline \multicolumn{2}{|l|}{ c. Cluster of $\operatorname{Stn}$ 9: } \\
\hline Bathyporeia elegans & 268 \\
\hline Tellina fabula & 65 \\
\hline Magelona spp. & 32 \\
\hline Amphiura filiformis & 30 \\
\hline Edwardia spp. & 28 \\
\hline Ophelia limacina & 27 \\
\hline Bathyporeia guilliamsoniana & 25 \\
\hline Spiophanes bombyx & 22 \\
\hline Urothoe poseidonis & 22 \\
\hline Goniada maculata & 20 \\
\hline Nephtys hombergii & 20 \\
\hline Montacuta ferruginosa & 18 \\
\hline
\end{tabular}

clusters' are established: Stns $1 \& 2$, Stns $4 \& 5$, Stns 7 $\& 8$, with Stns 3, $6 \& 9$ being transitional. Table 1 gives the dominant species for the assemblages of 1990 .

A similar grouping and ordination of the stations along the overall gradient was found using Multidimensional Scaling for abundance and biomass, Stn 9 in both cases being distinctly different from its neighbouring stations (Fig. 5).

ABC curves were plotted in order to obtain an indication of 'stress' within the communities. Fig. 6 shows that, with the exception of Stns $1,3 \& 4$, all the other communities appeared to be moderately (Stns 2, 5, 7 $\& 8$ ) or highly disturbed (Stns $6 \& 9$ ). One has to con- sider, however, that sampling took place at the end of winter. During winter opportunistic species normally decrease drastically, by which overall abundances and dominances, particularly at the inshore Stn 1, were affected (where only 6 species were found).

\section{DISCUSSION}

In general we can say that the differences found in the macrofauna along the transect, using descriptive (univariate) statistics as well as cluster analysis and MDS plots, reflected (1) the increasing distance from the very specific situation of the inner German Bight, and (2) the sediment dependent community distribution in the German Bight as described in principal already by Hagmeier (1925) and again by Salzwedel et al. (1985):

- the (impoverished) Nucula-nitidosa- (former Abraalba-) community in the inner German Bight on mud (Stns 1 to 3);

- the Amphiura-filiformis-community of the Pleistocene valley of the River Elbe on muddy sands (Stns 4 to 8 , forming 2 clusters: more inshore - more offshore); and

- an assemblage forming a transition from the Amphiura-filiformis - to the Tellina-fabula- former Venusgallina-) community at the border of the Dogger Bank on fine sands with a small amount of mud (Stn 9).

The potential impact of pollution and eutrophication on community structure, at first glance, appears to be confounded by the community's dependence on sediment characteristics and distance to shore.

Nevertheless, with the exception of the impoverished inshore Stns $1 \& 2$ and the intermediate ones (3 \& 4), the $A B C$ curves indicate that offshore assemblages along the profile have been disturbed (Fig. 6), due to a shift towards high numbers of small, shortlived species with low biomass (Kröncke 1988, 1990, Rachor 1990). Such changes have been described by several authors for communities subjected to high levels of organic matter or increasing eutrophication (Reise 1982, Pearson et al. 1985, Rosenberg et al. 1987). Bottom trawling with heavy fishing gear may produce similar changes, e.g. by removal of large, long-lived animals, thus favouring the predominance of adaptive, smaller forms.

In several instances changes within the German Bight communities have been related to anthropogenic causes. Rachor $(1977,1990)$ explained these changes as being mainly due to enrichment of organic matter. For the Nucula-nitidosa-community (found on muds), as well as for the Amphiura-filiformis-community (on muddy sands), Rachor (1990) found increases in biomass from 1923 to 1966 and up to $1975 / 1984$. Biomass 
may still have increased on muddy sands and sands, but stagnated or episodically recessed on muds due to the repeated occurrences of oxygen deficiencies since the seventies. Such oxygen deficiencies have been demonstrated for larger areas, including sandy stretches (Rachor 1977, Rachor \& Albrecht 1983, von Westernhagen et al. 1986). Accordingly, the Nuculanitidosa-community exhibited the lowest number of species and individuals, as well as the lowest biomass during this investigation (Fig. 1a, b, c). Diversity and evenness were also at a minimum (Figs. 1d \& 2). Rachor's conclusions are supported by the work of Duineveld et al. (1987), who described an increase in biomass of Amphiura filiformis in the submerged Pleistocene valley of the River Elbe. Moreover, Kröncke $(1988,1990)$ found an increase in biomass for the Tellina-fabula-community on the Dogger Bank (fine sands) between 1950-54 and 1985-87.

There is evidence for increasing eutrophication of the German Bight according to regular investigations at Helgoland roads initiated in 1962 (Hickel et al. 1989, Radach \& Bohle-Carbonell 1990). The changes in the macrofauna communities, fitting to the model of Pearson \& Rosenberg (1978), indicate an increased input of organic matter. Concerning the model, the Stns 4 to 9 seem to be in the transitory state where partly 'positive' effects of the eutrophication such as increased individual numbers and biomass without strong influences on overall diversity occur. In contrast, Stns $1 \& 2$, and possibly Stn 3, seem to have reached or are approaching - the polluted or grossly polluted state, where only a few species are regularly present (with densities greater than 20 ind. $\mathrm{m}^{-2}$; cf. Table 1 ).

During the present study, in contradiction to all the factors stressed above, this was not revealed by the $A B C$ plots. We regard the $A B C$ method as weak, when a very specific abundance pattern is present due to e.g. predominance of recruits in summer, or as can be
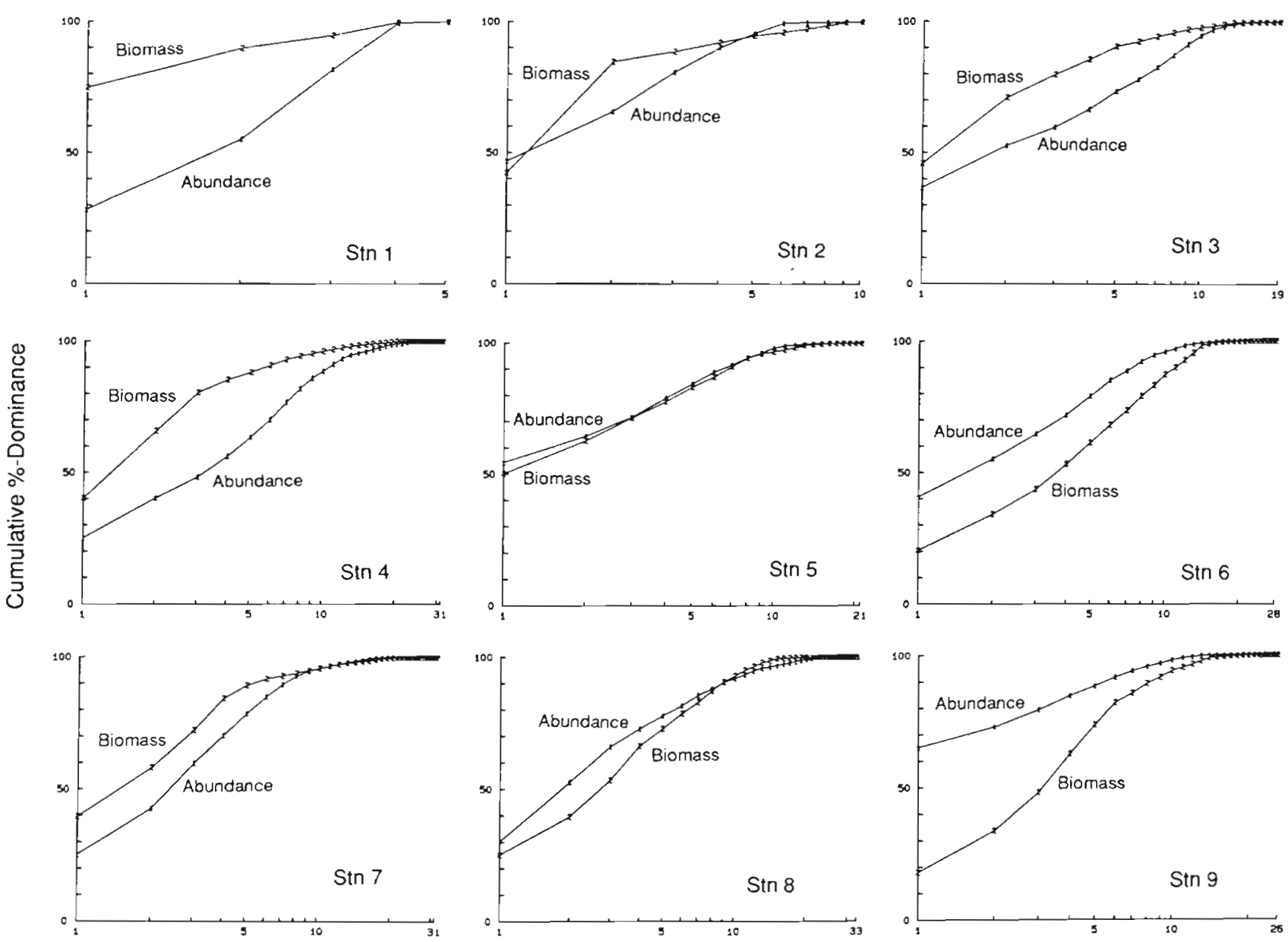

Species Rank

Fig. 6. ABC curves for Stns 1 to $9.1=$ Abundance $2=$ Biomass 
assumed for Stns 1 to 3 of this study, predominance of a few remaining species after an oxygen depletion in late summer, combined with the normal winter decrease in density due to natural mortality, including effects of low temperatures and disturbances by strong storms.

As additional stress factors for the bottom fauna of the inner German Bight the high concentrations of several contaminants in the sediments (Cofino et al. 1992) have to be taken into consideration to explain the gradients found. However, the macrofauna studies performed during the present investigation, do not allow discrimination between such effects and the background of natural fluctuations and disturbances by enrichment of organic matter and oxygen depletion.

Normally decreased concentrations of contaminants are expected towards the open sea, yet increases of concentrations for several heavy metals and hydrocarbons in the fine fraction of the sediments and biota on the Dogger Bank (Stn 9) were reported by Cofino et al. (1992). Irion \& Müller (1987), Kröncke (1987), Borchardt et al. (1988) and Kersten \& Klatt (1988) reported similar findings from heavy metal analyses of sediments and biota. The higher toxicity of Dogger Bank sediments (Kersten \& Kröncke 1991) therefore might have affected the macrofauna community structure on the Dogger Bank.

A complete set of benthic community data for the workshop is available from M. Carr, Plymouth Marine Laboratory, UK

Acknowledgements. We are grateful to Dr G. Duineveld, Dr $R$. Knust and to the crews of the research vessels 'Holland' and 'Victor Hensen' for their help with sampling. Thanks are due to Dr H. Eicken for correcting the English manuscript.

\section{LITERATURE CITED}

Borchardt, T., Burchert, S., Hablizel, H., Karbe, L., Zeitner, R. (1988). Trace metal concentrations in mussels: comparison between estuarine, coastal and offshore regions in the southeastern North Sea from 1983 to 1986. Mar. Ecol. Prog. Ser. 42: 17-31

Cofino, W. P., Smedes, F., de Jong, S. A., Abarnou, A., Boon, J. P., Oostingh, I., Davies, I. M., Klungsøyr, J., Wilhelmsen, S., Law, R. J., Whinnett, J A., Schmidt, D., Wilson, S. (1992). The chemistry programme. Mar. Ecol. Prog. Ser. 91: $47-56$

Bray, J. R., Curtis, J. T. (1957). An ordination of the upland forest of Southern Wisconsin. Ecol. Monogr. 27: 225-349

Duineveld, G. C. A., Künitzer, A., Heyman, R. P. (1987). Amphiura filiformis (Ophiuroidea: Echinodermata) in the North Sea. Distribution, present and former abundance and size composition. Neth. J. Sea Res. 21(4): 317-329

Hagmeier, A. (1925). Vorläufiger Bericht über die vorbereitenden Untersuchungen der Bodenfauna der Deutschen Bucht mit dem Petersen-Bodengreifer. Ber dt. wiss. Kommn Meeresforsch. N.F.1. 247-272

Hickel, W., Bauerfeind, E., Niermann, U., von Westernhagen, H. (1989). Oxygen deficiency in the south-eastern North
Sea: sources and biological effects. Ber. Biol. Anst. Helgoland 4: 1-148

Irion, G., Müller, G. (1987). Heavy metals in surficial sediments of the North Sea. In: Lindberg, S. E., Hutchinson, $T$ C. (eds.) Heavy metals in the environment, Vol. 2. CEP Consultants Ltd., Edinburgh, p. 38-41

Jaccard, P. (1912). The distribution of the flora of the alpine zone. New Phytol. 11:37-50

Kersten, M., Klatt, V. (1988). Trace metal inventory and geochemistry of the North Sea shelf sediments. In: Kempe, S., et al. (eds.) Biogeochemistry and distribution of suspended matter in the North Sea and implications to Fisheries Biology. Mitt. geol.-paläont. Inst. Univ. Hamb., SCOPE/ UNEP Sonderbd. 65: 289-311

Kersten, M., Kröncke, I. (1991). Bioavailability of lead in North Sea sediments. Helgoländer Meeresunters. 45: 403-409

Kröncke, I. (1987). Lead and cadmium concentrations in selected macrofauna species from the Dogger Bank and the eastern North Sea. Helgoländer Meeresunters. 41: $465-475$

Kröncke, I. (1988). Macrofauna standing stock of the Dogger Bank. A comparison: I. 1951-52 versus 1985. In: Kempe, S., et al. (eds.) Biogeochemistry and distribution of suspended matter in the North Sea and implications to Fisheries Biology. Mitt. geol.-paläont. Inst. Univ. Hamburg, SCOPE/UNEP Sonderbd. 65: 439-454

Kröncke, I. (1990). Macrofauna standing stock of the Dogger Bank. A comparison: II 1951-52 versus 1985-87. Are changes in the community of the northeastern part of the Dogger Bank due to environmental changes? Neth. J. Sea Res. 25(1/2): $189-198$

Kruskal, J. B., Wish, M. (1978). Multidimensional scaling. Sage Publications, Beverly Hills, California

Lambshead, P. J. D., Platt, H. M., Shaw, K. M. (1983). The detection of differences among assemblages of marine benthic species based on an assessment of dominance and diversity. J. nat. Hist. 17: 859-874

Omori, M., Ikeda, T. (1984). Methods in marine zooplankton ecology. Wiley \& Sons, New York

Pearson, T. H., Rosenberg, R. (1978). Macrobenthic succession in relation to organic enrichment and pollution of the marine environment. Oceanogr. mar. Biol. Ann. Rev. 16: $229-311$

Pearson, T H., Josefson, A. B., Rosenberg, R. (1985). Petersen's benthic stations revisited. I. Is the Kattegat becoming eutrophic? J. exp. mar. Biol. Ecol. 92: $157-206$

Pielou, E. C. (1969). An introduction to mathematical ecology. Wiley, New York

Rachor, E. (1977). Faunenverarmung in einem Schlickgebiet in der Nähe Helgolands. Helgoländer wiss. Meeresunters. 30: $633-651$

Rachor, E. (1990). Changes in sublittoral zoobenthos in the German Bight with regard to eutrophication. Neth. J. Sea Res. 25(1/2): 209-214

Rachor, E., Albrecht, H. (1983). Sauerstoffmangel im Bodenwasser der Deutschen Bucht. Veröff Inst. Meeresforsch. Bremerh. 19: 209-227

Radach, G., Bohle-Carbonell, M. (1990). Strukturuntersuchungen der meteorologischen, hydrographischen, Nährstoff- und Phytoplankton- Langzeitreihen in der Deutschen Bucht bei Helgoland. Ber. Biol. Anst. Helgoland 7: $127 \mathrm{pp}$.

Reise, K. (1982). Long-term changes in the macrobenthic invertebrate fauna of the Wadden Sea: are polychaetes about to take over? Neth. J. Sea Res. 16: 29-36 
Rosenberg, R., Gray, J. S., Josefson, A. B., Pearson, T H. (1987). Petersen's benthic stations revisited. II. Is the Oslofjord and the eastern Skagerrak enriched? J. exp. mar. Biol. Ecol. 105: 219-251

Sanders, H. L. (1968). Marine benthic diversity: a comparative study. Am. Nat. 102: 243-282

Salzwedel, H., Rachor, E., Gerdes, D. (1985). Benthic macrofauna communities in the German Bight. Veröff. Inst. Meeresforsch. Bremerh. 20: 199-267

Shannon, C. E., Weaver, W. (1972). The mathematical theory of communication, 5th edn. University of Illinois Press. Urbana

Stebbing, A. R. D., Dethlefsen, V. (1992). Introduction to the
Bremerhaven Workshop on Biological Effects of Contaminants. Mar. Ecol. Prog. Ser. 91, 1-8

Warwick, R. M. (1986). A new method for detecting pollution effects on marine macrobenthic communities. Mar. Biol. 92: $557-562$

Warwick, R. M., Pearson, T. H., Ruswahyuni (1987). Detection of pollution effects on marine macrobenthos: further evaluation of the species abundance/biomass method. Mar. Biol. 95: 193-200

Westernhagen, H. von, Hickel, W., Bauerteind, E., Niermann, U., Kröncke, 1. (1986). Sources and effects of oxygen deficiencies in the southeastern North Sea. Ophelia 26: 457-473 